Article

\title{
Democracy and Education through the Eyes of Kuwaiti Politicians: A Phenomenological Study
}

\author{
Sara Alnufaishan * and Alanoud Alrashidi \\ College of Education, Kuwait University, P.O. Box 13281, Keifan 71953, Kuwait; alanoud.alrashidi@ku.edu.kw \\ * Correspondence: sara.alnufaishan@ku.edu.kw
}

Received: 12 February 2019; Accepted: 12 March 2019; Published: 15 March 2019

\begin{abstract}
Kuwait's Constitution defines the small Arab Gulf nation as a constitutional democracy led by a hereditary emirate, although outside observers have questioned the degree to which it is indeed democratic. Despite such scepticism, Kuwait has undoubtedly taken some steps to promote democratization, including the introduction of the Constitution and Human Rights (CHR) module to the national curriculum to teach high students about civics, democracy and rights. While previous studies have explored the perspectives of Kuwaiti students and teachers towards democracy in general and the CHR in particular, the perspectives of Kuwaiti politicians have not been previously explored. To better understand their perspectives of and experiences towards democracy and education for democracy, this study employed a phenomenological approach involving 15-to-30-min semi-structured interviews with five Kuwait politicians who have served as either Members of the Kuwaiti National Assembly or Ministers or both. The themes that emerged included Active Versus Passive Democracy, Homegrown Versus Imported Democracy, Culture and Democracy and Education for Democracy, which are discussed in greater detail in the article.
\end{abstract}

Keywords: democracy; education; Kuwait; human rights; politicians

\section{Introduction}

Many forms of Government have been tried and will be tried in this world of sin and woe. No one pretends that democracy is perfect or all-wise. Indeed, it has been said that democracy is the worst form of Government except all those other forms that have been tried from time to time [1].

As Winston Churchill asserted in the quote above, democracy is not perfect. Among the many imperfections of democracy, Dahl [2] and Schmitter and Karl [3] noted how the democratic process is slow, indecisive, bureaucratic, inefficient, frustrating and even unstable at times. These limitations of democracy might hamper its appeal to the people of some nations in the Middle East and North Africa (MENA), where democratization has not reached very far and where only a few nations could be considered somewhat democratic. For example, the Democratic Index of the Economist Intelligence Unit listed Israel and Tunisia as Flawed Democracies and Lebanon, Turkey, Morocco and Iraq as Hybrid Democracies [4]. Meanwhile, no MENA country is listed as a Full Democracy and in the Arabian Gulf region in particular, all of the nations are categorized as Authoritarian [4]. Among the Gulf countries, however, Rizzo claimed that Kuwait has gone the furthest in the democratization process by establishing a constitution as well as a parliamentary-like body of elected representatives called the National Assembly that in 2006 allowed women to serve as members [5].

Kuwait is a small, wealthy nation with an oil-based economy located in the Arabian Gulf region. It is surrounded by Saudi Arabia to the south, Iraq to the north and northwest and the Arabian Gulf to the east with only a small strip of Iraqi land between Kuwait and Iran, leaving Kuwait in a precarious position between competing regional powers. Along with Saudi Arabia, Bahrain, the United Arab Emirates, Qatar and Oman, Kuwait is part of the Gulf Cooperation Council (GCC). 
Like most Gulf nations, Kuwait is ruled by the head of the royal family, known as the Emir; unlike most Gulf nations, however, Kuwait has a distinct constitution that is the source of the rule of law for the nation and has a representative democratic body, that is, the National Assembly [5]. As defined by its constitution, Kuwait is a constitutional, hereditary emirate (Article 4) with a purported democratic system of government and Islam is the official state religion (Article 2), although the rights of followers of other religions are to be respected and the freedoms of belief unrestricted (Article 35) [6]. Although Kuwait boasts a constitution and a National Assembly, the power of the National Assembly has been questioned; instead of a legislative body, it has been likened to what Rawl's called a consultation hierarchy [7-9] and instead of democratic, it has been called semi-democratic [10].

Despite the limitations of its democratic systems, Kuwait appears to want to promote greater democratization as evidenced by the fact that in 2006, Kuwait introduced an educational module in its national high school curriculum called the Constitution and Human Rights (CHR) module (Arabic transliteration: al-dostoor wa hoqooq al-insan), which began as a three-year program but was later reduced to a one-year course [11-13]. The CHR program is based on the principles of the universality of human rights and the values of the Kuwaiti Constitution [14]. It is designed to educate high school students on the principles of democracy, the Kuwaiti constitution and human rights and can be roughly characterized as a combination of civic education with human rights education [12]. The CHR program has been characterized as the first national human rights educational program in the Gulf region and was initially introduced to Grades 10, 11 and 12 [12]. In Grade 10, students were introduced to the fundamentals of democracy and human rights; in Grade 11, students learned about human rights from the perspectives of Islam, international agreements and the Kuwaiti Constitution; and in Grade 12, students studied the details of the Kuwaiti system of government, including the democratic components, the Constitution and the distribution of power. Al-Nakib [12,13] remarked that the CHR program radically shifted the approach to civic education in Kuwait from a focus on national citizenship and nationalism towards the promotion of democratic participation and the ideals of universal human rights.

However, in 2009, the three-year CHR program was reduced to one year in Grade 12. The only official explanation for these cuts appeared in 2010 in a brief report for Kuwait's Universal Periodic Review presented to the UN's Office of the High Commissioner for Human Rights, which stated.

The Ministry has decided that it is much better to teach this subject in the final stage of secondary school (twelfth grade). The learner in this grade is intellectually and psychologically ready for such specialised information about democracy, the Constitution and human rights [14] (p. 12).

Other than this report, the Kuwaiti government has not made public the official reasons for these changes [12]. Currently, the CHR textbook for Grade 12, now in its second edition as of 2018, is divided into two units with three chapters each. Unit One focuses on the Kuwaiti Constitution, with chapters on shura and democracy, the development of the democratic system in Kuwait and legislative power [15]. Unit Two focuses on human rights from historical, universal and Kuwaiti/Islamic perspectives [15]. Taken together, the CHR curriculum teaches democracy and human rights together without clearly addressing their distinctions. Indeed, as Al-Nakib wrote, the CHR program is characterized by "a tangling of terms" used in the fields of human rights, democracy, citizenship and nationalism [11] (p. 166). At the very least, it should be understood that the relationship between human rights and democracy are enshrined in Article 21 of the Universal Declaration of Human Rights, which states, "Everyone has the right to take part in the government of his country, directly or through freely chosen representatives" [16].

\subsection{Statement of the Problem}

As the process of democratization develops in Kuwait, it offers a unique opportunity to explore the perceived role of education in the early stages of the process and the types obstacles encountered along the way. While previous research has explored the perspectives of educators and students [11-13], there have been no academic articles that have explored the experiences of politicians in Kuwait. 


\subsection{Statement of Purpose}

To explore this topic, we have established two purposes of the research: (1) to understand how democracy is experienced in Kuwait and (2) to understand the perspectives of Kuwaiti politicians towards education for democracy in Kuwait.

\subsection{Research Questions}

To achieve the purposes of the research, the following two research questions were posed:

1. How do Kuwaiti politicians experience and understand democracy in Kuwait?

2. How does this experience and understanding inform their perspectives toward education for democracy in Kuwait?

\section{Literature Review}

\subsection{Democracy and Education}

In the first chapter of his book On Democracy, Dahl posed the rhetorical question, "Do We Really Need a Guide?" to democracy, which he proceeds to answer in the affirmative throughout the rest of the book [2]. Indeed, without some kind of educational guide that explains the origin (s), definition, history, philosophy, principles, procedures, variations and socio-cultural conditions of democracy, democracy would be ineffective at best and corrupted for harmful purposes at worst. Dahl considered the goal of such an educational guide to be "enlightened understanding," which can be achieved through civic education [2].

Because democracy depends on participation from the citizens of a nation, it is in the best interest of a democracy to have an educated populace. According to Dahl, the need for civic education continues to grow with changes in scale, complexity and communication because more voices need to be heard and considered in the process [2]. With all the voices involved, one important learning outcome civic educators must strive for is promoting an understanding of the limitations and problems of democracies. For instance, Schmitter and Karl [3] noted that democracies are not necessarily more economically efficient, are not necessarily more administratively efficient, are not necessarily more stable or orderly and do not necessarily have more open economies. So, someone used to growing up in an autocratic society may be disappointed by the inefficiencies, complications and slow-moving processes of democracies, especially if they were on a side that benefited from the efficiencies of an autocracy that may have been unjust to others.

\subsection{Kuwait}

As a nation, Kuwait is both young and small and has been relatively stable and peaceful. From 1752 until today, all of the rulers of Kuwait have been in the Sabah family, which is important to note because the Kuwaiti identity is therefore closely linked to the royal family [17]. Throughout this period of Sabah rule, Kuwait vacillated between the Ottoman Empire, British protection and independence. The history of Kuwait is so closely linked with Britain, in fact, that many scholars such as Tétreault [18] have called it a British Client State. As part of the agreement, from the 1930s to the 1960s Britain encouraged reforms that led to the formation of the National Assembly (a parliament-like body) and the creation of the constitution. Ultimately, Kuwait established itself as an independent constitutional monarchy between 1961-62 [19].

Rights in Kuwait are protected by the nation's constitution, which was created in 1962, suspended during Iraqi occupation of 1990 and reinstated in 1992. In many other Gulf nations, such as Saudi Arabia, the Quran serves as the constitution of the nation, while Kuwait is unique in the region for having a separate constitutional document. While the constitution does emphasize the supremacy of the Quran and Islamic laws in Part I, Article 2, stating, "The religion of the State is Islam and Islamic Law shall be a main source of legislation," it goes beyond the Quran and does not state that Islamic 
Law is the only source of legislation. The clause that the Quran is the main but not only source of law grants non-Muslim Kuwaitis more freedom than in neighbouring nations. The constitution includes five main parts that define the structure of the state and system government, the foundations of society, the public rights and obligations, the powers of different bodies of government and various other general and temporary provisions. Most of the rights are outlined in Part III and include the following:

- Freedom of religion

- Freedom of press

- Outlawing slavery

- Presumption of innocence

- Right to free education

- Right to healthcare [6]

However, in some cases some rights can be suspended. As Al-Nakib explained, "The Amir [sic] also has the power to dissolve parliament when the government and parliament cannot co-operate (Article 102 of the Kuwaiti Constitution) and this has resulted in four parliamentary elections between 2005 and 2012" [12] (p. 99). In total, the Kuwait National Assembly has been dissolved nine times in 55 years, with only six National Assemblies being able to complete their terms [19]. Alnajjar highlighted some moments in Kuwaiti history when freedoms were suspended and democratization slowed, noting in particular the effects of the Iran-Iraq War (1980-1988) and Iraqi Occupation of Kuwait during the Gulf War (August 1990-February 1991) [20]. As Kuwait emerged from war, "International pressure, particularly by human rights NGOs [non-governmental organizations], played a major role in pushing and paving the way for quick and structural recovery of instruments safeguarding human rights" [21] (p. 209).

More recently, democratization in Kuwait has extended to women's rights. In 2005, women got the right to vote and serve in Kuwait National Assembly [22]. Following this decision to give women the right to vote and serve in elected office, the first election women could actually vote or serve in occurred in 2006 but no woman won any National Assembly seats [22]. Since no woman won any seats in National Assembly that year, the Emir named the first woman as a minister in his government, which is a non-elected position [22]. The first time a woman became a member of National Assembly occurred in 2009 when four women won seats; however, in 2012 no women won seats in the National Assembly [23]. Finally, in the 2016 election, only one woman won a seat in the National Assembly although 15 ran [24].

\subsection{Democracy and Civic Education in Kuwait}

As democracy struggles to emerge in some parts of the MENA region, often violently as evident in the Arab Spring, civic education needs to emerge along with it. In Kuwait, the Ministry of Education introduced the CHR civic and human rights education program to its national curriculum, which Al-Nakib has written about extensively [11-13]. Over time, the CHR changed drastically: it started in 2006 as a three-year curriculum for Grades 10-12 but was reduced to a one-year course in Grade 12 in 2008; however, Kuwaiti government has not made public the official reasons for these changes [11]. Furthermore, the focus of the curriculum has shifted away from civic participation. Al-Nakib explained:

With a focus on the Kuwaiti constitution, international human rights and the democratic process, the CHR module set Kuwait on a track away from patriotic and nationalistic education towards critical democratic education. However, this was derailed once the module was rescinded. As it stands now, the grade 12 textbook, which has not yet been rescinded, deals exclusively with the government branches and division of power in Kuwait [11] (p. 174).

Al-Nakib asserted that in the absence of human rights education and any form of student participation, it reduced the module to education about democracy rather than education through or for democracy [11]. Citing interviews with Kuwaiti students, Al-Nakib [11] found that the lack of 
a participative classroom and the lack of substantial opportunities for participation in the Kuwaiti system of government, most of the democratic lessons rang hollow. Thus, more work needs to be done to promote civic education that encourages participation if one expects the development of democratic practices in the future. However, other than Al-Nakib's research on the perspectives of teachers and students, little is known about how other groups of Kuwaitis perceive the value of the CHR or similar curricula for civic and human rights education, including the perspectives of politicians in Kuwait.

\section{Materials and Methods}

Even though Rizzo referred to Kuwait as the most democratic nation in the Gulf and the nation promotes some democratic ideas in its education system, not much is known about how Kuwaitis perceive democracy and education for democracy. The limited previous research has focused on the perspectives of students and sometimes teachers [12] but until now no studies have investigated the perspectives of Kuwaiti politicians in terms of how they see democracy developing in Kuwait.

\subsection{Research Design}

To explore how Kuwaiti politicians with expertise in education, law and religion perceive the role of democracy and education in Kuwait, we conducted interviews using a qualitative design with a phenomenological approach. A qualitative design was appropriate for this study for exploratory purposes [25], as it is a new area of research with very little known about Kuwaiti politicians' perspectives. Qualitative research is best suited for research problems where the variables are unknown and the literature provides little information about the phenomenon of study [26]. In this case, the phenomenon of study is how Kuwaiti politicians experience and understand democracy and education for democracy. Because the focus is on the politicians' experiences toward and understandings of democracy and education for democracy, a phenomenological approach is most appropriate.

\subsection{Context and Participants}

The participants were all bounded by similar experiences, with all participants being Kuwaitis who have served in the government in some capacity in recent years and have an interest in democracy and education. The inclusion criteria were as follows:

- Participants must be adult Kuwaitis, either male or female.

- Participants must have served in the government, whether in the National Assembly or in one of the Ministries.

- Participants must be recognized politicians with expertise in the fields of education, law or religion.

- Participants must agree to participate.

The participants were selected using purposive sampling with the intent to achieve maximal variation in perspectives and political leanings within the constraints of the selection criteria. Thus, we aimed to recruit participants who considered themselves liberal, conservative and independent. We also aimed to gather both male and female perspectives but the limited number of female Kuwaiti politicians in government posed a challenge. Moreover, we strived to gather information from both Ministers and Members of the National Assembly for every area of expertise, as represented in the following matrix (Table 1): 
Table 1. Matrix of participants by experience for maximal variation. As this matrix shows, participant 1 satisfied two of the criteria for areas of expertise, so in the end there were five participants instead of six.

\begin{tabular}{cccc}
\hline & Education & Law & Religion \\
\hline $\begin{array}{c}\text { National Assembly } \\
\text { Ministry }\end{array}$ & Participant 2 & Participant 5 & Participant 3 \\
& Participant 4 & Participant 1 & Participant 1 \\
\hline
\end{tabular}

Participants were recruited by reaching out to our contacts to see if they had connections with Kuwaitis who met the inclusion criteria and we also used social media platforms to invite qualified participants. Some of the potential participants worked at the same university as we do, so we were able to contact them easily and others were representatives in our districts and make themselves available to constituents. For one potential participant, we reached out to him and his son via Twitter to invite him to participate and his son shared his father's contact information with us. We also tried to contact some female members of the National Assembly via social media but none responded to our invitations.

Five participants agreed to participate and fit the inclusion criteria, all of whom were males despite efforts to include female perspectives. The credentials and political positions of these five participants can be described as follows:

1. Ph.D. in Sharia (Islamic law), Professor of Law, former Minister of Justice, former Minister of Islamic Affairs and sharia scholar.

2. Ph.D. in Education, Professor of Education, College of Education, former Department Chair and a former Member of the National Assembly.

3. Ph.D. in Sharia (Islamic law), former Member of the National Assembly and sharia scholar.

4. Ph.D. in Law, former Minister of Education and served as a member of the National Assembly four times

5. Ph.D. in Law, Professor of Law, Visiting Professor at a prominent private U.S. university and former Member of the National Assembly.

Although the participants gave permission to use their names, we chose to remove their names and use descriptions of their positions to minimize the potential risk they may face if their published words were to get used against them. However, we also included enough description of their current and former positions to provide a meaningful context within which their responses could be interpreted. The experiences of these participants are tied in part to the distinct contexts of each of their roles and positions. It is important to note, therefore, that the National Assembly is a governing body whose members are elected by the Kuwaiti people and are responsible for deliberating on issues, legislating and consulting the administration, while the Ministers of the various Ministries, however, are appointed to the position by the Prime Minister who is appointed by the Emir.

\subsection{Data Collection}

Data were primarily collected using semi-structured interviews. The interviews were researcher-designed and consisted of 12 questions, which were developed based on the findings of previous literature of research on Kuwaiti democracy [11-13,21]. The 12 questions were developed in English first and were reviewed by an expert in English and education. We then translated the questions into Arabic and an Arabic-English translation expert reviewed the translation for accuracy. The English interview questions were as follows:

1. Are Kuwaiti citizens generally active in politics in our country? How so?

2. In your opinion, should Kuwaiti citizens be more active in our political process? Why or why not?

3. In your time in the Ministry/National Assembly, what sort of conversations and debates about promoting democratic ideals or principles in Kuwait were discussed, if any? 
4. To your knowledge, what are some currently existing political bodies and processes in Kuwait that are democratic and promote democratic ideals?

5. To your knowledge, what are some aspects of Kuwaiti culture that seem conducive to democracy locally and nationally, such as shura councils and similar traditions?

6. What are some aspects of Kuwaiti culture and politics that seem completely incompatible with democracy?

7. What are some the challenges Kuwait faces in moving towards more democratic practices?

8. What are some problems with democracy itself that you think people need to be aware of?

9. How can Kuwaitis be encouraged to be more active in politics and citizenship?

10. Can education help Kuwaitis be more politically active? Why or why not

11. The CHR is an educational program implemented in high school curriculums throughout Kuwait. Are you able to discuss more about its current status and possible future directions? Where is it headed? Are you able to discuss why was the CHR curriculum reduced from three years to one year in 2010 ?

12. What age/grade should we start teaching citizenship/democracy (CHR)?

Because of the semi-structured nature of the interviews, we asked variations of these 12 questions with different follow-up questions based on their responses. All of the interviews were conducted in Arabic in locations that were considered comfortable for the interviewees. The interviews were recorded using an iPhone.

\subsection{Data Preparation}

The interview recordings were transcribed in Arabic and then translated into English for analysis. The translations were reviewed by the authors of this study in addition to a colleague in the US who is bilingual in English and Arabic and has a bachelor's degree in Arabic-to-English translation. All of the interviews were conducted within a three-day period. A single interview was conducted with each participant, with no follow-up interviews. Each interview lasted approximately 15-30-min. Locations included either the interviewees' university offices (Participants 1, 2, \& 5) or their homes (Participants $3 \& 4)$. The interview for Participant 3 was conducted in the salon room of his house, which is an area commonly used for receiving guests in Arabian Gulf cultures. Participant 4 was conducted in his diwan, which is a room traditionally for men to sit and discuss local and national affairs, politics and other social topics. It is worth noting that Participant 4 made a unique exception for me as a woman to meet with me in the diwan room (which was a sign of respect and an indicator in his belief in democracy). One interviewee (Participant 3 ) requested the questions in advance, while all others heard the questions for the first time during the interview.

\subsection{Data Analysis}

Once the interviews were transcribed and translated, the English translation was analysed qualitatively to determine commonalities and themes. To increase the validity of the analysis, a peer review strategy was employed. The translated interviews were uploaded onto Google Docs and were analysed by three educational researchers: the two authors of this article and one colleague in the US. Each data analyser reviewed the transcripts and identified keywords and concepts that appeared in most or all of the interviews. These common terms were coded and were summarized in a table arranged by participant and question. To establish consistency and reliability between the coders, we used a negotiated agreement method, which, as Campbell, Quincy, Osserman and Pedersen explained, involves the following steps: "researchers code a transcript, compare codings and then discuss their disagreements in an effort to reconcile them and arrive at a final version in which as many discrepancies as possible have been resolved." [27] (p. 305). In accordance with this approach, the three coders first coded the transcripts separately, then compared the codings to determine the level of agreement and disagreement between the codes and finally discussed the disagreements to 
resolve the differences. Based on the analysis, themes emerged that are introduced and discussed in the next two sections along with key quotes that exemplify each theme.

\section{Results}

The two purposes of this qualitative study were to understand how democracy is experienced in Kuwait and to understand the experiences of Kuwaiti politicians towards education for democracy. Based on the interviews, the following four themes emerged: Active Versus Passive Democracy, Culture and Democracy, Homegrown Versus Imported Democracy and Education for Democracy. Each theme is organized by the research question it helped answer and is explained with relevant quotes and interpretations.

\subsection{Research Question 1}

\subsubsection{Active versus Passive Democracy}

Most of the participants except Participant 5 agreed that Kuwaiti people are currently active in politics; however, three of the participants $(1,2, \& 4)$ did not think Kuwaitis should be more active. The participants that were against more political activity all said different versions of the same thing: that there needs to be more expertise and knowledge about politics to exercise political power responsibly, with some participants even saying that political activity should be left for those who specialize in politics just like medicine is left to medical doctors who specialize in the field. For example, Participant 4 stated:

I think there has to be some kind of specialty. I mean, today we have professional associations like those in the medical field, in which you will find a greater part of their lectures are political than in their own specialty.

Participant 4 explained further that if people focused on their profession and specialty, it would indirectly benefit the political situation in Kuwait anyway. He clarified that he did not mean people should not be involved in politics at all but that there needs to be a balance. He cautioned against everyone getting involved in political criticism all the time, stating, "Criticism is always easy; you can criticize anything but criticism along with offering an alternative or a solution is the important part of the process and the correct and most beneficial approach." The general consensus among all the participants seemed to be that there needs to be some exclusivity in the political process.

Participant 5 differed from most of the participants in terms of his opinion on both the question of current level of political activity among Kuwaitis and the question of whether they should be more active. He expressed uncertainty about both. While all of the other participants stated that Kuwaitis are active in politics, Participant 5 stated, "I am not sure." He stated that there is definitely an interest towards being politically active among Kuwaitis but in terms of their understanding of what that means and the degree to which their activity amounted to much, he was not so sure. Unlike the other participants that thought the general population needed more knowledge and should leave most decisions to the political experts, Participant 5 also expressed his doubts that anyone in Kuwait, even the politicians, has a strong understanding of various aspects of democratic systems, such as political action and deliberation.

Another interesting point to note is that one of the most extremely conservative participants, Participant 3, stated that Kuwaiti people should be more active in politics. His reasoning is as follows: "If we stay at home without any participation, there sure will be a law voted on, by the National Assembly and thus we don't have the right to object because we are not there at the National Assembly to express our opinion." In other words, if people want their voices heard and if they want to express any objections, they need to show up and be active. Thus, even though he was the most critical of some democratic ideals, Participant 3 saw the value in participating if that's the system that currently exists. 


\subsubsection{Culture and Democracy}

In the theme of Kuwaiti culture and democracy, some tension between the two social forces emerged: while some aspects of Kuwaiti culture seem conducive to democracy, other aspects do not. Some aspects of traditional Kuwaiti culture that the participants cited as examples that are conducive to democracy included the practices of shura and diwaniya. Shurais exalted in Islam as a necessary component of determining the wisest course of action and decisions that align with the needs of the community and align with Islamic law. Shura essentially means "consultation," but more specifically refers to "consultation of Islamic scholars." These bodies essentially serve as advisory boards for politicians in which the opinions of multiple Islamic scholars are heard and weighed before policy decisions are made. Indeed, Participants 1, 2 and 3 mentioned the practice of shura and consultation as quasi-democratic aspects of Kuwaiti culture.

Participant 1 stated, "Our regime is based on Shura; it is stated in the Explanatory Memorandum of the Constitution that the regime is based on Shura and this is a democratic principle." He then provided a couple examples of this principle in action:

His highness, the Emir, does not assign a crown prince; he nominates a person and the National Assembly, which represents the general public, is the one who assigns or rejects. And this is a prominent application of democracy in the regime.

Additionally, If the National Assembly, which is the general public, passes a law and His Highness, the Emir, vetoes it, the Assembly has the right to re-vote, override the veto and apply the law with the power of the Assembly. The Emir cannot reject it and has to approve it and then refer it to the government for implementation.

These two examples highlight how the National Assembly is not just an advisory or consultative board but also has some legislative power.

Participant 3 mentioned the cultural aspect of tribal consultation as well, stating that "Consultative elections in tribes in general," is a cultural element conducive to democracy. He described this practice as "a tribe with its intensity and position in each constituency, has a culture based on consultation, shura, which is democracy." Interestingly, though, consultation among tribes is outlawed in Kuwait because, while it is democratic on a tribal level, it can easily devolve into tribalism and racism at a national level where the majority tribes can oppress the minority groups in an undemocratic fashion. Thus, tribal elections, also called tribal primaries [28], held before the official National Assembly elections are against the law, although they sometimes still occur secretly during other social gatherings such as funerals or weddings [29].

Participant 4 mentioned another aspect of Kuwaiti culture that is semi-democratic and that is the practice of diwaniya. The diwaniya is a traditional gathering of men who discuss politics and social issues. At a family, tribal or neighbourhood level, a consensus among this gathering can lead to decisions with some political power that can change the structures and systems of the local social groups $[28,29]$. Like other tribal practices that are semi-democratic, though, the problem with this practice is its exclusivity, being primarily for men and exclusive to members of the tribe or social group. At the national level, these traditional aspects of culture can actually threaten the open, public and more transparent democratic systems.

The elements of Kuwaiti culture that the participants said go against democracy are social customs and traditions, the influence of extremely wealthy people, imposition, not respecting others' opinions and finally, racism and tribalism. Participant 5 also mentioned the fact that even at the earliest ages, there are cultural values that can promote or discourage democratic ideals. Participant 5 noted that an important value to cherish in a democracy is "how to respect equality, how to respect others: For example, in America, when you go to any kindergarten, children stand in line and if you try to cut the line, they won't accept it! But this is a different perception than the Kuwaiti child!" Even something as simple as respect the fairness and orderliness of lines can work against the principles of democracy in the long run according to Participant 5. 


\subsubsection{Imported Versus Homegrown Democracy}

The cultural differences between Kuwait and Western democracies brought up the theme of how democratization can successfully develop in Kuwait. Ideas about imported or foreign concepts and native or homegrown processes and institutions emerged. Defining the state of democracy in Kuwait, Participants 1 described it as "premature" and "hybrid," meaning it has not fully matured into its own Kuwaiti form of democracy and instead borrows aspects from different governments, such as parliamentarism combined with an executive branch led by the Emir (Articles 51 and 52 in Kuwait Constitution) [6]. Participant 1 further warned against the direct importation of other democratic principles. For example, “the Kuwaiti system doesn't believe in the absolute individual freedom as it is in the foreign liberalism, which is in very big conflict with the Islamic principles." He concluded that it is possible to be democratic in a Kuwaiti way, stating, "I believe in democracy, I believe in freedom but not your understanding of freedom in the absolute!" Participant 2 also noted that Kuwait does not quite have its own democracy but in a more critical way, noting, "with all my respect to Kuwait and other third world countries but they are all deficient in their democratic practices, not like America and Britain and the European countries who practice the real democracy with their constitutions."

Participant 4 summarized the issues overall and proposed a realistic resolution to some of the conflicts discussed by the other participants. He stated,

"There is no system in the world that is free of defects. Democracy has advantages and disadvantages but it is up to the strength and the intelligence of the society to make it successful. Some may say we want America's democracy or Europe's democracy. No, you can't take a system from another country and apply it to your country. Each country has its own values and traditions and cultures. You must have the ability to design a democratic system that goes with the values of your society and the nature of your society. Like we said, democracy does not have one form. Democracy is a platform for freedom through which people are able to participate in decision making for their country."

His acknowledgement of the flaws of all systems is reminiscent of Churchill's quote that opened this article and his description of democracy as a platform upon which a people can build its own version of democracy reveals his in-depth understanding of democratic principles and local realities.

There was common agreement among the participants that democracy in Kuwait needs to have its own identity based on the sociocultural context and the will of the people. As Participants 4 noted, there is no single form of democracy but it can provide a platform upon which the people can build their own system rooted in democratic principles, values and thoughts. The emphasis on a democratic platform as a foundation for people to form their own system indicates a support for a bottom-up approach to democracy in Kuwait. As Participant 4 stated, "You must have the ability to design a democratic system that goes with the values of your society and the nature of your society."

Conversely, even the most conservative participants criticized top-down approaches to democracy in the interviews. For example, Participant 3 mentioned, "imposing something in the name of democracy without consultation, this will be an obstacle" to democracy. This is an important point to keep in mind when pursuing a goal of democratizing the world. Even though there may be good intentions to promoting democracy, if it is done in a way that is imposed from the top-down with little to no input from the local people, it will likely fail.

\subsection{Research Question 2}

\section{Education for Democracy}

All but one participant (Participant 3) agreed that the current CHR curriculum for civic education is not enough. Only Participant 3 thought it was enough to teach about democracy and human rights in Grade 12 because there are more important and useful subjects to teach. He stated, "I don't see the need for teaching this course to younger students and it is enough for the 12th grade," and explained 
the reason for the reduced number of years in the CHR curriculum was appropriate because there is no need to "keep a high school student in the 10th and 11th and 12th grades busy with such a course. There are more beneficial and better scientific courses than this course." Furthermore, he claimed, "Kuwaitis, thanks to God, have a high cultural knowledge in democracy and the Kuwaiti Constitution."

All the other participants, however, strongly disagreed with the idea that Kuwaitis have enough knowledge of democracy and politics and emphasized the need to start teaching it at an earlier age. Participant 5 stated, "I prefer that it is taught even before this level [12th grade], not necessarily the whole constitution but some of the rules that are compatible to the age of the man, such as the concept of equality: you don't have to be 15 to study it, because you are born with it." The idea of teaching underlying values and principles of democracy at earlier ages before teaching the specific processes and procedures was a common theme.

Participant 4 stated, "in the elementary school and middle school and high school and kindergarten," the schools can "teach freedom and its definition, teach democracy and its definition, as principles and practices. More important than principles is teaching practices." However, Participant 4 thinks that teaching about the specific details of the Kuwaiti Constitution and political system is best left for professors at the university level. Participant 4 also expressed his concerns about the lack of teacher preparation to teach such courses with democratic values integrated throughout the curriculum. He stated, "an integrated course for teacher development does not exist" to prepare teachers to integrate, although he emphasized it should exist.

Likewise, Participant 1 stated, "Some courses should be endorsed in the earlier levels, such as basic laws, reinforcing citizenship, the principles of affiliation and analysing the concept of citizenship, the duties and the responsibilities of the citizen and the responsibilities of the country, because it is a mutual relationship" in order to increase "maturity and awareness where every citizen knows his rights and obligations and was raised on them and knows his rights." But Participant 1 also noted that in-depth legal education "might only be needed by the deputies, because there are a lot of things, the average citizen has nothing to do with."

\section{Discussion}

Even though the participants hold differing political positions and may disagree with each other on how democracy should exist and be developed in Kuwait, they all tend to agree on some of the principles of democracy. That's the key with democracy: despite differing opinions and in part because of them, democracy can still flourish as long as some important values are shared.

The responses from the participants revealed two interesting patterns in terms of their experiences and understanding of democracy. One pattern was that the participants who were former Members of the National Assembly (Participants 2, 3 and 5) were much more critical of the Kuwaiti system and the state of democracy there than the former Ministers of various Kuwaiti ministries (Participants 1 and 4). Perhaps because the National Assembly is a more democratic body in which the Members are used to voicing their opinions and debating sides, the participants who had that experience felt freer to voice controversial or critical points of view. The other pattern was that the participants who might be considered as more extreme on the conservative or liberal spectrum by Kuwait standards (Participants 3 and 5, respectively) were most in favour of greater amounts of active participation from the Kuwaiti people than the more moderate/centrist participants (1,2 and 4). The reason for this finding might be because people who want to make a change one way or another need more support and activity to do so, while those satisfied with the status quo probably do not want to upset the order through a drastic change in the level of participation. Indeed, previous research has found "those holding the polar positions are more likely than those in the middle to attempt to sway others' votes" [30] and that social media users on the extreme ends of the political spectrum tend to be more active and constitute a "vocal minority" [31]. Thus, despite having very different socio-political ideologies, by promoting 
greater political activity from the populace, Participants 3 and 5 shared a common means to their opposing ends.

It was somewhat surprising that the participants that seemed most supportive of democratic ideals and education also were some of the most opposed to more political activity among the Kuwaiti people. On one level, it may seem self-contradictory. However, the sentiment is understandable in a nation that is not a mature democracy and is still transitioning and building upon its democratic institutions. The interviewees' responses when it comes to democratic action and education interesting dilemma. Most of these scholars expressed support for democracy and education for democracy but these same scholars balked at the idea of Kuwaitis being more active in politics because they are not ready. Unfortunately, education alone is not enough; there needs to be some degree of democratic participation, political activity and exercise of rights to make the lessons meaningful and impactful. As Participant 5 mentioned, Kuwaitis should be more active in politics because political decisions are not personal decisions; they affect everyone, so Kuwaitis should be aware of ongoing debates and decisions and have input in the process.

Previous research from Al-Nakib identified a similar problem: students noticed the CHR curriculum sounded good but did not reflect the reality of Kuwaiti society and politics [14]. In other words, the lessons in the curriculum did not ring true and seemed to contradict the reality Kuwaiti students observed and experienced. So, the dilemma here is if education for democracy is promoted without promoting more political activity, then students will likely see through the veneer of a superficial democracy. Yet, at the same time, promoting more democratic activity and granting more power to people who are not well versed in democratic principles, values, ideals and processes can lead to the failure of the system. A people needs to have some experience with democracy in order to develop a stable democracy but from where does that experience come?

One possible resolution to this challenge of civic education faced by new and transitioning democracies is presented by Dahl through a process he called "incrementalism" [2]. Incrementalism in civic education is the step-by-step introduction of education alongside complementary changes to the political system so that knowledge of and experience with democracy can develop side-by-side. Otherwise, promoting knowledge without experience rings hollow while experience without knowledge is immature.

Contradictions between democratic ideals versus the real-life practices in the democratization process in Kuwait, such as those pointed out by Participant 5, have been identified in previous research as well. In her analysis of the tangling of terms and concepts in the CHR curriculum, Al-Nakib concluded, "Arguably the most crucial thing this module did, however, was to bring to the surface the inconsistencies and tensions between several of the concepts it was meant to educate about" [12] (p. 175), these concepts being democracy, human rights and citizenship. Al-Nakib later described how the CHR's "incorporation into the existing authoritarian structures lessened its potential impact" [13] (p. 104) and constituted "a thin contribution to education for democratic citizenship" [13] (p. 105). For these reasons, it is important to be aware of ways in which the lessons of the CHR are potentially contradicted by the structure of Kuwaiti schools and society so that these apparent inconsistencies can potentially be discussed and constructively criticized.

The fact that four of the participant promoted education for democracy and human rights from early grades was encouraging and also resonated with findings from Al-Nakib [13]. She found the three-year CHR curriculum allowed for a "thicker enactment of democratic education," even within an authoritarian school system, "with students developing agency, questioning the status quo and taking action" compared to the "thinner" one-year course [13] (p. 110). This finding reinforce the need for a longer and more comprehensive CHR curriculum in Kuwait that incorporates basic values and behaviours that are conducive to democracy at early ages, such as justice, equality, respect and fairness, which can branch out and become more advanced at higher levels.

The question remains as to whether the CHR (or similar) curriculum should be integrated into other courses or if it should be a separate course. If a CHR course is a separate class, it runs the risk of 
being thin, meaningless and an easy elective for students. If it is worked into other subjects, it could be more meaningful and relevant but it might be eroded from the courses over time in favour of the more fundamental lessons in the subject area. Al-Nakib stated, "introducing education about human rights and democracy as a separate subject ensured it was not lost in the curriculum or appropriated by other subjects" [13] (p. 104). In contrast, Beane noted, "many teachers in search of democratic methods have come to the conclusion that teaching the democratic way eventually involves moving beyond the separate subject approach to the curriculum toward approaches that integrate knowledge through problem-centred units" [32] (p. 1065).

Finally, a recommendation expressed by Participant 4 was that not only should education focus on students but must also focus on teacher development so that the lessons are taught effectively. Al-Nakib noted that "While the Kuwaiti government has stated its commitment to education for democratic citizenship ... it has yet to lay out explicit aims and proposed outcomes and to provide necessary teacher training" [13] (p. 166). However, to this day, teacher training for CHR in Kuwait is lacking and should be further developed.

\section{Conclusions}

All participants agreed on the basic values of democracy and agreed that Kuwaitis and Kuwaiti culture contain aspects that are open to democracy. There was also a general consensus that democracy in Kuwait must be developed from within rather than imposed from outside. A common concern among the participants was the worry that Kuwaitis in general lack some awareness and understanding of democracy and political action, which are important to know in order to participate in democracies in a responsible way. Thus, education for democracy is essential in order for a mature democratic system to emerge in Kuwait. To this end, it was generally agreed upon that education for democracy should start from early age, based on simple, fundamental democratic values and behaviours early on and working up to more and more advanced, complex, abstract and critical elements in the final years. The current CHR curriculum, unfortunately, is not serious and is not committed. A one-year elective, which is not a core or required course, is not enough. Whether the lessons of democracy are integrated into other subjects and connected to real life or taught in a separate course, it is necessary to intentional, deliberate and committed to the plan. Right now, it seems, CHR is an afterthought, not a priority.

This study was limited by its small sample size, which is a common limitation in qualitative research; However the study was also limited by the lack multiple sources of data, such as focus group interviews, document analyses and follow-up interviews, which are typically used in qualitative research to make the data more robust. Ideally, the interviews would have involved a follow-up interview to clarify any vague responses as well as to conduct a member checking methodology; however, the participants' schedules and time constraints did not allow for this step to be conducted. Unfortunately, the lifestyles of the participants limited their availability. Likewise, the selection process was based on convenience and led to an all-male sample of politicians, which was the result of the extremely limited number of female Kuwaiti politicians to begin with.

There also still remains a need to spell out more fully the nature and meaning of democracy as it is understood in general in Kuwait; however, it was beyond the scope of this article to address the national trends or interpretations of democracy, to the extent to which it would even be possible to characterize the entire nation of Kuwait, it would require a wide-scale survey that goes far beyond existing research as well as the limits of this article. Future research should focus on gathering more nationwide data on Kuwaitis attitudes towards human rights education and democracy. We remain hopeful that a clearer picture of the meaning of democracy to Kuwaitis will emerge in the coming years as research in this area continues to develop.

Author Contributions: Conceptualization, S.A. and A.A.; Methodology, S.A.; Validation, S.A. and A.A.; Formal Analysis, S.A. and A.A.; Investigation, S.A.; Resources, S.A.; Data Curation, S.A. and A.A.; Writing-Original Draft Preparation, S.A.; Writing-Review \& Editing, A.A. 
Funding: This research received no external funding.

Acknowledgments: We would like to acknowledge the help of Clayton Chiarelott with the editing and formatting of the final manuscript.

Conflicts of Interest: The authors declare no conflict of interest.

\section{References}

1. Churchill, W.S. Speech to House of Commons, November 11, 1947. In Winston S. Churchill: His Complete Speeches, 1897-1963; James, R.R., Ed.; Chelsea House: New York, NY, USA, 1974; Volume 7, p. 7566.

2. Dahl, R.A. On Democracy; Yale University Press: New Haven, CT, USA, 1998.

3. Schmitter, P.C.; Karl, T.L. What democracy is ... and is not. J. Democr. 1991, 2. Available online: http:/ / www. ned.org/docs/Philippe-C-Schmitter-and-Terry-Lynn-Karl-What-Democracy-is-and-Is-Not.pdf (accessed on 20 January 2019). [CrossRef]

4. The Economist Intelligence Unit Democracy Index 2018: Me Too? Available online: http:/ /www.eiu.com/ topic/democracy-index (accessed on 13 January 2019).

5. Rizzo, H.M. Islam, Democracy, and the Status of Women; Routledge: New York, NY, USA, 2017.

6. Kuwaiti Constitution. Available online: http://unpan1.un.org/intradoc/groups/public/documents/undpadm/unpan039795.pdf (accessed on 20 January 2019).

7. Rawls, J. The Law of Peoples; Harvard University Press: Cambridge, MA, USA, 1999.

8. Alnufaishan, S. Peace Education Reconstructed: How Peace Education Can Work in Kuwait. Ph.D. Thesis, University of Toledo, Toledo, OH, USA, 2018.

9. Doyle, M. One world, many peoples: International Justice in John Rawls's the Law of Peoples. Perspect. Politics 2006, 4, 109-120. Available online: https:/ / doi.org/10.1017/S1537592706060117 (accessed on 20 January 2019). [CrossRef]

10. Kinninmont, J. Kuwait's Parliament: An Experiment in Semi-Democracy; Chatham House: London, UK, 2012.

11. Al-Nakib, R. Citizenship, nationalism, human rights and democracy: A tangling of terms in the Kuwaiti curriculum. Educ. Res. 2011, 53, 165-178. Available online: https://www.tandfonline.com/doi/abs/10. 1080/00131881.2011.572364 (accessed on 20 January 2019). [CrossRef]

12. Al-Nakib, R. Human rights, education for democratic citizenship and international organisations: Findings from a Kuwaiti UNESCO ASPnet school. Camb. J. Educ. 2012, 42, 97-112. Available online: https: / /www. tandfonline.com/doi/abs/10.1080/0305764X.2011.652072 (accessed on 20 January 2019). [CrossRef]

13. Al-Nakib, R. Education and Democratic Development in Kuwait: Citizens in Waiting. Available online: https:/ / www.chathamhouse.org/publication/education-and-democratic-development-kuwait-citizenswaiting (accessed on 20 January 2019).

14. Ministry of Education. The State of Kuwait: Experience in the Field of Human Rights Education; Ministry of Education: Kuwait City, Kuwait, 2010.

15. Curriculum Department, Ministry of Education. Constitution and Human Rights [Al-dustar wa huqdq al-insdn], 2nd ed.; Ministry of Education: Kuwait City, Kuwait, 2018.

16. Universal Declaration of Human Rights. Available online: http://www.un.org/en/universal-declarationhuman-rights (accessed on 20 January 2019).

17. Al-Nakib, F. Kuwait Transformed: A History of Oil and Urban Life; Stanford University Press: Stanford, CA, USA, 2016.

18. Tétreault, M.R. Autonomy, necessity, and the small state: Ruling Kuwait in the twentieth century. Int. Organ. 1991, 45, 565-591. Available online: https://www.researchgate.net/publication/46545006_Autonomy_ necessity_and_the_small_state_ruling_Kuwait_in_the_twentieth_century (accessed on 20 January 2019). [CrossRef]

19. Casey, M.S. The History of Kuwait; Greenwood Press: Westport, CT, USA, 2007.

20. Toumi, H. Kuwait Parliament Dissolved Nine Times in 54 Years. Available online: http:/ / www.timeskuwait. com/Times_Kuwait-parliament-dissolved-nine-times-in-54-years (accessed on 20 January 2019).

21. Alnajjar, G. Human Rights in a Crisis Situation: The Case of Kuwait after Occupation. Hum. Rights Q. 2001, 23, 188-209. Available online: https://www.researchgate.net/publication/295555995_Human_rights_in_a_ crisis_situation_The_case_of_Kuwait_after_occupation (accessed on 20 January 2019). 
22. Gorvett, J. Kuwait making history. Middle East 2006. Available online: https://www.thefreelibrary. $\mathrm{com} /$ Kuwait+making+history\%3a+Kuwaitis+were+preparing+to+cast+their+votes+in...-a0148368607 (accessed on 20 January 2019).

23. Kuwaiti Women Still Battling for Legal and Political Recognition. Available online: https://www.alaraby. co.uk/english/society/2016/5/11/kuwaiti-women-still-battling-for-legal-and-political-recognition (accessed on 20 January 2019).

24. Cohn, L. 15 Female Candidates Ran for Parliament in Kuwait's Latest Election-Only This Woman Won. Available online: http://fortune.com/2016/11/28/kuwait-parliament-election-women/ (accessed on 20 January 2019).

25. Creswell, J.W. Educational Research: Planning, Conducting, and Evaluating Quantitative and Qualitative Research, 4th ed.; Pearson: Boston, MA, USA, 2012.

26. Creswell, J.W. Qualitative Inquiry and Research Design: Choosing among Five Traditions; Sage: Thousand Oaks, CA, USA, 1998.

27. Campbell, J.L.; Quincy, C.; Osserman, J.; Pedersen, O.K. Coding In-depth Semistructured Interviews. Sociol. Methods Res. 2013, 42. Available online: https://www.doi.org/10.1177/0049124113500475 (accessed on 20 January 2019). [CrossRef]

28. Tétreault, M.A. Patterns of culture and democratization in Kuwait. Stud. Comp. Int. Dev. $1995,30$. Available online: https:/ /link.springer.com/article/10.1007/BF02802952 (accessed on 20 January 2019). [CrossRef]

29. Khalid, S.M. Emerging Patterns of Political Participation in the GCC States. Ph.D. Dissertation, Jamia Millia Islamia, Delhi, India, 2018.

30. Hansen, S.B. Talking about politics: Gender and contextual effects on political proselytizing. J. Politics 1997, 59. Available online: http:/ / www.pitt.edu/ \{\}polisci/joparticle.html (accessed on 20 January 2019). [CrossRef]

31. Mustafaraj, E.; Finn, S.; Whitlock, C.; Metaxas, P.T. Vocal Minority Versus Silent Majority: Discovering the Opinions of the Long Tail. In Proceedings of the 2011 IEEE Third International Conference on Privacy, Security, Risk and Trust, MIT, Boston, USA, 2011.

32. Beane, J. Teaching for Democracy's Sake. Rev. e-Curric. 2017, 15. Available online: https://www.doi.org/10. 23925/1809-3876.2017v15i4p1050-1080 (accessed on 20 January 2019). [CrossRef] 